\title{
An integrated approach to design of new biotechnological products to reduce man-induced load on environment Belovezhets L.A. ${ }^{l}$, Tretyakova M.S. ${ }^{2}$, Markova Yu.A. ${ }^{2}$ \\ ${ }^{1}$ IRIH SB RAS, Irkutsk, Russia; ${ }^{2}$ SIFIBR SB RAS, Irkutsk, Russia \\ E-mail: lyu-sya@yandex.ru
}

Key message. The regularities of transformation of complex organic substrates (oil, sawdust, hydrolysis lignin) by microbial associations have been established.

Keywords: microorganisms, lignocellulose substrates, oil destruction, integrated approach

Industrial and communal human activities are accompanied by strong atmospheric pollutant emission. Currently, the most promising methods for soil remediation are based on the application of a variety of microorganisms and microbial communities.

The present work is aimed at the development of an integrated approach to the biotransformation of lignocellulosic substrates and oil by microorganisms.

It is found that the processes occurring during composting of lignocellulosic waste and remediation of soil from oil have similar features. It is proved that the observed surge in the phytotoxicity of the transformable substrate is due to the effective activity of oxidoreductase enzymes and an increase in the number of microorganisms, which differ in substrate specificity and type of nutrition. Consequently, this accelerates all the processes, thereby significantly reducing the transformation time. After 3-4 months, all indicators of biological activity are normalized, and toxicity does not differ from the control that evidences the completion of the substrate transformation and efficiency of the drugs. Correspondingly, the processes, which without treatment usually last for decades, in the presence of microorganisms take 2-3 months to afford almost non-toxic products. In addition, the comprehensive studies reveal a multi-faceted biological activity of microorganisms, incorporated in the drug composition, which positively affects the properties of the processed lignocellulosic waste and remediation of soil from oil. For instance, it is established that the microorganisms exhibit phytostimulating effect due to their ability to synthesize biologically active substances such as amino acids and phytohormones. It is also found that the microorganisms can synthesize biosurfactants. The structure and main physical-chemical properties of these surfactants have been studied. It is shown that the effect of these compounds on plant survival under the conditions of soil contamination with oil is owing to emulsification of the oil film on the root surface.

The study was supported by a grant from the Russian Foundation for Basic Research, project No. 20-016-00114 A.

\section{Комплексный подход к созданию новых биотехнологических препаратов для снижения техногенной нагрузки на окружающую среду Беловежеи Л.А. ${ }^{1}$, Третьяков М.С. ${ }^{2}$, Маркова Ю.А. ${ }^{2}$ \\ ${ }^{1}$ ИрИХ СО РАН, Иркутск, Россия; ${ }^{2}$ СИФИБР СО РАН, Иркутск, Россия}

\begin{abstract}
Аннотация. В результате работы выявлены закономерности трансформации сложных органических субстратов (нефть, опилки, гидролизный лигнин) микробными ассоччициями.

Ключевые слова: микроорганизмы, лигноцеллюлозные субстраты, нефтедеструкция, комплексный подход
\end{abstract}

Производственная и бытовая деятельность человека сопровождается выбросом в окружающую среду большого количества загрязняющих веществ. В настоящее время наиболее перспективными являются методы ремедиации, использующие разнообразные микроорганизмы и микробные сообщества.

Целью работы была разработка комплексного подхода к биотрансформации лигноцеллюлозных субстратов и нефти микроорганизмами.

Результаты исследования выявили однотипность процессов, происходящих при компостировании лигноцеллюлозных отходов и ремедиации почв от нефти. Доказано, что наблюдаемый всплеск фитотоксичности трансформируемого субстрата происходит за счет эффективной деятельности оксидоредуктазных ферментов и увеличения численности микроорганизмов, различных по субстратной специфичности и типу питания. Это приводит к ускорению всех процессов, что значительно сокращает сроки трансформации. Через 3-4 месяца все показатели биологической активности нормализуются, а токсичность не отличается от контроля, что свидетельствует об окончании трансформации субстратов и эффективности препаратов. Соответственно, процессы, без обработки растягивающиеся на десятилетия, происходят в течение 2-3 месяцев и приводят к полному отсутствию токсичности продукта. Кроме того, в результате комплексного исследования выявлена многофакторная биологическая деятельность микроорганизмов, входящих в состав препаратов, позитивно влияющая на свойства переработанных лигноцеллюлозных отходов и очистку почвы от нефти. Так, установлено фитостимулирующее действие микроорганизмов, основанное на их способности синтезировать биологически активные вещества, такие как аминокислоты и фитогормоны. Выявлена способность микроорганизмов синтезировать биогенные поверхностноактивные вещества - биосурфактанты, исследованы их структура и основные физико-химические свойства. Доказано, что влияние этих соединений на выживаемость растений в условиях загрязнения почвы нефтью происходит за счет эмульгирования нефтяной пленки на поверхности корней.

Исследование поддержано грантом РФФИ, проект № 20-016-00114 А. 